\title{
The criticality of integrating local agro-economic institutions into paradigms for least developed countries in the epoch of the Anthropocene
}

\author{
M. Davidson \\ Claremont Graduate University, USA
}

\begin{abstract}
Climate-smart agriculture (CSA) interlinks and provides for the two most critical issues for human and ecological sustainability: providing food for impending population growth to reduce poverty and undernourishment, and managing for eco-system resilience in the context of global environmental change. Implementation of CSA in smallholder communities in the least developed countries (LDCs) has proven successful but has not been widely adopted. This paper examines the constraints to replicable and generalizable adoption of CSA methodologies and posits that the absence of professional, local, agro-economic institutions is a key variable that explains the stagnation of agricultural production and the increase in greenhouse gas emissions from the agricultural sector. The strategies of the development community (NGOs, development banks, international and national aid institutions) focus on funding large scale irrigation projects, encouraging and supporting new technologies, and correcting perceived market failures. The development community has not engaged professional agricultural organizations and institutions and this disconnect has led to ineffective interventions on the part of the development community. This paper further posits that farming is not an activity that can be sustained by the strategies and tactics of the development community. Agriculture is a business enterprise that requires local agro-economic institutional support.

Keywords: climate smart agriculture, Anthropocene, agricultural dealers, least developed countries, agro-economic institutions.
\end{abstract}




\section{Introduction}

Reliable and valid evidence shows that the Millennium Development Goals (MDGs) for hunger, undernourishment and poverty reduction will not be achieved by 2015 [1] and data show that countries most vulnerable and least resilient to environmental hazards closely correlate to the United Nations list of LDCs [2]. The number of extremely poor people in LDCs $(<\$ 1 /$ day/capita) increased by over 3 million from 2002 to 2007 to 1.3 billion, the distribution of people in the adult population earning less than $\$ 1.25 /$ day doubled from $18 \%$ to $36 \%$, and 2.6 billion live on less than $\$ 2 /$ day. The total number of people in LDCs who are undernourished $(<3000 \mathrm{kcal} /$ day/capita) increased by over 5 million from 2002 to 2007 [3]. The Food and Agriculture Organization (FAO) of the UN indicates that the 852 million of undernourished people in the world has remained unchanged since 1990 and 815 million, or 95\%, are in LDCs [1].

While these figures are reason for concern, they increase in urgency when one takes into account: projections that between 2011 and 2100 the population of highfertility countries, which highly correlates to LDCs and includes most of subSaharan Africa, will triple, passing from 1.2 billion to 4.2 billion [4]; "reports indicate that per capita food production is actually declining in parts of subSaharan Africa" [5], and; "new data suggests that rainfed crop yields in some African countries are projected to decline by 50 per cent by 2010 due to climate change" [6].

Over the past ten years agricultural production has remained virtually stagnant, increasing by less than $2 \%$ per annum [7].

To cope with a $40 \%$ increase in world population and to raise average food consumption to a target of $3130 \mathrm{kcal} / \mathrm{cap} /$ day by 2050 "agricultural production...will need to increase by $70 \%$ overall, and by 100 percent in developing countries. This translates into an additional billion tons of cereals and 200 million tons of meat to be produced annually by 2050, as compared with production in 2005/07" [7]. Since $85 \%$ of sub-Saharan Africa's poor, for example, depend largely on agriculture for their livelihoods, agricultural growth is clearly key to poverty reduction [8].

Agricultural growth has a positive impact on poverty reduction. Estimated elasticities of poverty indicate that: "on average, a 1-percent increase in agricultural productivity level will reduce incidence of poverty by 0.31 percent. Additionally, a 1-percent increase in equity index for land distribution will reduce poverty by 0.48 percent" [1]. Furthermore, evidence indicates that improvements in irrigation highly correlate with greater yields. Case studies establishing the linkage between irrigation systems and poverty reduction are many - in Kenya [2]; Pakistan [3]; Ethiopia [4]; and Burkina Faso [5], for example - and report direct and indirect benefits of irrigation, including increased farmer consumption and assets.

Agriculture is also the major cause of global greenhouse gas emissions, and "climate variability is the primary determinant of agricultural productivity" [6]. Therefore, sustainable agricultural methodologies and practices need to serve as mitigation tools for reducing greenhouse gas emissions, and be adaptable to 
changing environmental conditions due to climate change. In traditional agricultural regimes "raising crop and livestock directly contributes an estimated $10-12 \%$ of anthropogenic greenhouse gas emissions globally" (Smith et al 2008 quoted in [7]. "Indirect total emissions caused by agricultural production accounts for about one-third of all greenhouse gas emissions" [7]. A defining characteristic of traditional farming is to increase yields by extensive production rather than intensive production. Extensive agriculture refers to expanding and increasing the hectares under production while intensive agriculture refers to improving yields on current agricultural land. "The transition from forested land to agricultural fields is the most significant cause for increases in $\mathrm{CO}_{2}$ " [8]. Because agricultural irrigation consumes $70 \%$ of the world's consumptive water, and agricultural land occupies $36 \%$ of the Earth's arable surface [9] the degree to which food demands are met, poverty and undernourishment significantly reduced, and a safe space for human development [10] created, depends upon the integration of the institutions of agriculture and irrigation into a conceptual framework that is implementable, adaptable, science-based, and operational on multiple scales.

The temporal and spatial context for this paper is the Anthropocene, the new epoch in Earth history [11] that is distinguished by the sizeable and significant human imprint on the global environment. The anthropogenic impacts of humankind on the global environment have been quantified by Rockstrom et al. and codified into Planetary Boundary Theory. In this theory, "climate change is only one of a number of planetary boundaries that make up the Earth-system processes and associated thresholds that, if crossed, could generate unacceptable environmental changes" [8]. Of particular salience for this paper is that land and water management is key to mitigating the seven, currently quantifiable, planetary boundaries. "Water and land management are the primary media through which climate change will impact people, ecosystems and economics" [12].

This paper posits that the critical agents required to achieve the objectives of CSA sustainably, are the local, professional, agro-economic institutions and organizations whose success and livelihoods are inextricably interlinked with the success of the local farming community.

This paper is organized in the following manner: the next section will define the characteristics of CSA and provide illustrations of where the methodologies of CSA have been applied and implemented in several African LDCs and the extent to which the three objectives of: improved production; adaptation to environmental change, and; mitigation of deleterious environmental impacts have been achieved. The following section will delineate the constraints to widespread adoption of CSA and the failure of development strategy to overcome these obstacles. The next section will focus on the criticality of integrating local agroeconomic institutions for the purpose of implementing sustainable CSA regimes. This section will focus on the local irrigation dealer and explain why and how the dealer (also referred to as the distributor) is the key agent required in order to establish a sustainable regimen for climate smart agriculture. This paper closes with a brief analysis of the generalizability of the dealer model. 


\section{Climate smart agriculture}

Climate smart agriculture, also called sustainable agricultural production, innovative irrigation systems, and farming system innovations is implemented when growers draw from a tool kit consisting of instruments and methods to increase agricultural production and mitigate environmental changes. The outcomes of CSA are improved yields and a reduction in deleterious environmental impacts. "The idea of agricultural sustainability centres on food production that makes the best use of nature's goods and services while not damaging these assets" [13].

\subsection{Tools and methods of CSA}

The tools that have proven effective at improving yields and mitigating environmental damage include: conservation tillage; intensive cultivation; integrated pest and nutrient management; utilization of green (rain) water; water harvesting; runoff diversion; improved drainage; terracing; efficient irrigation, etc. Case studies show significant and positive economic benefits from practicing sustainable agricultural practices [14] and McCarthy et al. [15].

A key study elegantly illustrates the "synergies and tradeoffs between productivity, climate change adaptation, and greenhouse gas mitigation" [17]. Bryan et al. list the activities of sustainable agriculture (productivity impacts) and corresponding climate adaptation benefits and greenhouse gas mitigation potential and finds that improved crop varieties; changing plant dates; improved crop rotation with legumes; appropriate use of fertilizer and manure; incorporation of crop residues; reduced tillage; agroforestry; irrigation and water harvesting; bunds; terraces; mulching; grass strips; ridge and furrow, and; diversion ditches, all increase yields (with the excepted impact of reduced likelihood of crop failure for the 'changing plant date' activity) and all have positive mitigation potential. Reganold et al. point out that "sustainable agriculture does not represent a return to pre-industrial revolution methods; rather it combines traditional conservationminded farming techniques with modern technologies. Sustainable systems use modern equipment, certified seed, soil and water conservation practices and (the)...emphasis is placed on rotating crops...and controlling pests, naturally" [18].

\subsection{Yield and mitigation impacts of CSA}

Makurira et al. compared a combination of three methods of sustainable agriculture which he terms "farming system innovations" [19]. His Tanzania project looked at the effects of runoff diversion (RD), on-site water harvesting (WH), conservation tillage (CT) at four sites using traditional hand-hoe methods and found that an increase of maize yields up to 4.8 tha $^{-1}$ over the current average of less than 1 tha $^{-1}$ [19]. Evidence shows that interventions to increase agricultural sustainability reduce pesticide use, increase yields and improve soil [13]. Studies showed "the extent to which 286 interventions in 57 poor countries covering 37 million ha (about $3 \%$ of the cultivated area in developing countries) have increased productivity on 12.6 million farms while improving the supply of critical 
environmental services" [13]. Sustainable agricultural practices such as minimum crop tillage and integrated pest and nutrient management regimes helped increase "average yields by 79\% (geometric mean 64\%). Potential carbon sequestered amounted to an average of $0.35 \mathrm{Gt} / \mathrm{Cy}$ (gross tons per calendar year). Of projects in Pretty's study with pesticide data, $77 \%$ resulted in a decline in pesticide use by $71 \%$ while yields grew by $42 \%$ " [13].

According to Bellarby et al. "the total global contribution of agriculture, considering all direct and indirect emissions, is between 8.5-16.5 $\mathrm{Pg} \mathrm{CO}_{2}$, which represents between 17 and $32 \%$ of all global human-induced GHG emissions, including land use changes" [20]. Bellarby et al. suggest that agriculture provides a wide range of mitigation options including: cropland management, restoration of organic soils, improved water and rice management, increasing the efficiency of fertilizers, etc. [20].

\section{Constraints to adoption of CSA}

Socio-economic challenges faced by LDCs need to be understood within the context of severe water scarcity. It is important to note that those most in need of poverty and undernourishment reduction live in the most water-scarce and environmentally vulnerable environments. Currently, about 700 million people in 43 countries suffer from water scarcity. A region experiences water stress when annual water supplies drop below $1,700 \mathrm{~m}^{3} /$ capita. When annual supplies drop below $1000 \mathrm{~m}^{3} /$ capita the population faces water scarcity, and when annual supplies drop below $500 \mathrm{~m}^{3} /$ capita the population faces absolute water scarcity [21]. "By 2025, 1.8 billion people will be living in countries or regions with absolute water scarcity, and two-thirds of the world's population will be living under water-stressed conditions [22]. Interventions to make the most efficient use of irrigation water for enhanced agricultural production under conditions of water scarcity while mitigating deleterious effects of the environment are beset by myriad complexities involving scale, governance [23], statutory v. traditional law [24], land tenure and water rights [25], infrastructure, institutional support, supply chains, education and agronomic support, marketing tools, etc. [26-28]. Other drivers that have been identified to explain the lack of productivity include: relatively low soil fertility; highly variable rainfall; lack of labor; extensive instead of intensive cultivation; unsupportive and de-motivating environments for growers; unreliable markets; out-of-date extension services [29].

\section{The failures of development to implement CSA}

The tools utilized by the development community generally fall within two broad categories: funding projects, and research and development of new technologies. To a lesser degree, the development community has also tried to provide incentives, subsidies, and other market tools to encourage growth. These interventions have not been successful at overcoming the aforementioned constraints and obstacles to enhanced production within the context of environmental change. 


\subsection{Funding for projects}

Agriculture has been the beneficiary of direct funding, subsidies, and research and development. From 1995 to 2009 total Net Official Development Assistance (ODA) to LDCs rose from $\$ 17$ billion to $\$ 40$ billion (in current US\$) [30]. In 2010 net ODA flows from members of the Development Assistance Committee (DAC) of the Organization for Economic Development and Cooperation (OECD) reached $\$ 128.7$ million, which is the highest level of aid in the history of the OECD [31]. The most complete source of data on government expenditures on agriculture in the countries of the developing world reports that the level of expenditures on agriculture for all 67 countries in the Statistics of Public Expenditure for Economic Development (SPEED) database increased from \$55 billion in Purchasing Power Parity (PPP) in 1980 to \$205 billion in 2007 [32]. By 2010 the total ODA from all sources to LDCs reached $\$ 400$ billion, up from $\$ 135$ billion in 2000 . During that same period annual growth from agricultural production in LDCs grew from $-1 \%$ in 2000 to $2 \%$ in 2010. As aforementioned, in order to keep up with projected population growth, agricultural production needs to increase by $100 \%$ by the year 2050 .

\subsection{Funding for research and development}

A central model for agricultural development from the middle of the 20th century onward has been to invest in agricultural research and development. The assumption by the development community is that "the world's agricultural economy underwent a remarkable transformation during the 20th century as the result of agricultural productivity growth, which was primarily generated by agricultural R\&D financed and conducted by a small group of rich countries especially the United States, but also Japan, the United Kingdom, France, and Germany" [33]. This refers to the Green Revolution of the 1960s and 70s, which was a period of phenomenal growth in agriculture due to intensive research to help transfer and adapt scientific advances to agriculture. "The breeding of improved varieties, combined with the expanded use of fertilizers, other chemical inputs, and irrigation led to dramatic yield increases in the developed world and Asia and Latin America" [34]. LDCs disproportionately experienced the negative externalities - environmental damage due to excessive use of fertilizers and pesticides that negatively affect waterways, agricultural workers and beneficial insects and other wildlife [34] - without benefiting from the increases in yields. A new "Doubly Green Revolution" [35] is required to significantly increase crop production in least developed countries (LDCs) while "conserving natural resources and the environment" [35]. "That is to say, an agricultural revolution that is even more productive than the first Green Revolution and even more green in terms of conserving natural resources and the environment" [35] is required. Approximately $\$ 37$ billion in total R\&D was generated, worldwide, in agriculture in 2000 but has dwindled somewhat since. The inability to generate a second Green Revolution, particularly in LDCs, is another indicator of the lack of coordination between the development community and professional agro- 
economic institutions and organizations. The nature of the professional agroeconomic institutions will be illustrated below.

\section{Critical agro-economic institutions}

Agricultural systems are managed ecosystems [6] that consume the greatest quantities of freshwater relative to other consumptive uses [36]. Irrigated agriculture is a key direct driver for poverty reduction and decreases in undernourishment and malnutrition [2, 3, 37, 38]. This paper posits that the "primary reasons why poverty, hunger, water scarcity, and environmental degradation continue to afflict developing countries are political and institutional, rather than technical, failings" [39]. That is to say, technology to achieve the MDG targets for poverty reduction through increased agricultural production is available today but local, institutional structures are found wanting in LDCs.

This paper posits that agriculture is a business enterprise that is supported by critical interconnected and complex agricultural institutions and organizations. The development community does not provide epistemic space for all appropriate and needed professional agricultural institutions and organizations. A disconnect exists between the institutions of agriculture and irrigation and the Development community - The World Bank Group, IWRM/Global Water Partnership (GWP), NGOs, non-agrarian academic institutions - as Merrey terms it, the "water management establishment" [40].

The agricultural organizations that are not institutionalized in LDCs and have not found a voice within the development community consist of agricultural colleges and universities; agricultural equipment and chemical manufacturers and sales agencies; irrigation trade organizations; agricultural dealers and distributors; irrigation designers; irrigation contractors; and growers.

\subsection{The irrigation dealer}

The criticality of the dealer goes beyond stocking and selling whole goods and spare parts. The dealer is aware that determining the proper type of irrigation system is a complex and nonlinear process. Details about crop selection, soil conditions, hydraulic parameters, capital costs, fixed and variable costs, cost-benefit, availability and support for materials, targets for uniformity of coverage, etc. are some of the necessary parameters to determine before a system is designed and components supplied. Corrections and modifications to the irrigation system, once it is operationalized, is a key component for efficiency and cost-effectiveness.

The dealer network performs the irreplaceable role of the local strategic, economic and educational link between the irrigation and agricultural implement manufacturers and the smallholder and agribusiness communities. The criticality of the dealer/smallholder relationship in the supply value chain is inextricably and interdependently linked to the profitability and growth of the smallholder. All components of irrigation systems break down and require ongoing repair and replacement. All irrigation and agricultural components require proper design, 
maintenance and a dynamic knowledge base for proper application. These are the primary tasks that the irrigation dealer performs and for which he/she is trained.

The dealer network stands in contradistinction to the unprofessional distributor of donated irrigation equipment. This knowledge gap or constraint is illustrated by Burney and Naylor [41], who describes the initial success of drip kits installed in sub-Saharan Africa only to find that dis-adoption, or an abandonment rate of drip kits of $84 \%$, after three years, due to a variety of technical and knowledge problems. Adopting more efficient technologies is a slow process because of a knowledge gap between "hydrological processes related to agricultural productivity and extension services towards actual in-field activities that contribute to farm productivity" [19]. In addition, You points out that: "Of the 6 million hectares presently equipped for irrigation, approximately 1 million hectares are in need of rehabilitation" [42].

The function of the irrigation dealer is to enable smallholders to achieve greater efficiencies, higher yields, and cost-effective methodologies for their farming operations, regardless of scale, within the context of good environmental stewardship. The dealer interfaces, on an exclusive basis, with manufacturers of irrigation, agricultural tool and implement, nutrient, and chemical manufacturers. The dealer serves as the wholesale procurer and distributor of equipment. It is the responsibility and commitment of the dealer to represent the products he/she sells honestly, at a fair market price, and provide support services for those products and their applications.

The dealer is not only the agent of the manufacturer and the grower. The dealer is the indispensable dissemination source for agricultural information for two reasons: 1) the task of informing individual smallholders about methodologies or technology by an academic institution or NGO is virtually impossible. In order for the dealer to become successful he/she must reach out to the smallholder community to develop a consistent customer base. One dealer will have direct access to hundreds or thousands of smallholder farmers; 2) the smallholder, like any farmer in the world, looks first to the dealer for support and information, on a regular basis. Irrigation is a dynamic process. All irrigation system components: pumps; valves; emitters; conveyance pipes; fittings, etc., need regular repair and maintenance.

The three critical interdependent actors that are interlinked and whose financial success depends on the success of the other two are the grower, the distributor and the manufacturer of equipment. The manufacturer is only successful if the distributor sells his equipment and the distributor is only successful if the grower purchase the equipment from her. Finally, the grower is only successful if the equipment purchased from the dealer performs according to its specifications and, as promised, is the appropriate equipment for the grower in time and space. This is the model employed by North American, Western European, Indian and South American farming communities. Dealers are formally trained in agricultural engineering or production. Many dealers (and all irrigation manufacturers) belong to The Irrigation Association, which "offers a number of certification programs for professionals specializing in agriculture" [43]. The Certified Agricultural irrigation Specialist (CAIS) is trained to manage and operate on-farm irrigation 
systems. The CAIS "understands surface irrigation methods and pressurized systems, including micro-irrigation and sprinklers; evaluates crops and determines water availability and use requirements; understands soil-plant-water relationships and how salinity affects irrigation; selects the most effective irrigation methods and equipment for the application, and develops efficient and cost-effective irrigation schedules that meet the crop's water requirement" [43].

\subsection{Generalizability of the dealer model}

The question remains as to the replicability, transferability and generalizability of the dealer network to the LDC community. The paucity of irrigation dealers in LDCs and concomitant stagnation of productivity sits in direct contrast to the proliferate dealer community in the developed world where agricultural production is robust.

\section{Conclusions}

The current development model has failed to increase agricultural production or mitigate the deleterious effects of agricultural regimes, particularly in LDCs. The funding allotted to achieving the MGD targets in agricultural production has proven ineffective. The methodologies employed and encouraged by the development community have proven inefficient. The failure of development is not benign as undernourishment, poverty and hunger will grow as the population increases in LDCs. The development community is dedicated to providing aid for agricultural production without accompanying support and recognition of critical, local, professional agro-economic institutions - in particular, the irrigation dealer network. The disconnection between the agro-economic institutions and the development community precludes successful implementation of technology and transfer of knowledge.

\section{References}

[1] Hussain I, Wijerathna D. Irrigation and Income-Poverty Alleviation: A Comparative Analysis of Irrigation Systems in Developing Asia. Colombo, Sri Lanka; 2004.

[2] Ngigi S, Thome J, Waweru D, Blank H. Low-cost irrigation for poverty reduction; 2010.

[3] Hussain M, Z H, Ashfaq M. Impact of Small Scale Irrigation Schemes on Poverty Alleviation in Marginal Areas of Punjab, Pakistan. International Research Journal of Finance and Economics, (6); 2006.

[4] Gebregziabher G, Namara R. Investment in irrigation as a poverty reduction strategy: Analysis of small-scale irrigation impact on poverty in Tigray, Ethiopia. IMAWESA; 2009. 
[5] Dembele Y, Yacouba H, Keita A, Sally H. Assessment of Irrigation System Performance in South-Western Burkina Faso. Irrigation and Drainage. 2011 September 27; 61: p. 306-315.

[6] Adams R, Hurd B, Lenhart S, Leary N. Effects of global climate change on agriculture: an interpretative review. Climate Research. 1998 December 17; 11: p. 19-30.

[7] Wollenberg E, Tapio-Biström ML, Grieg-Gran Me. Climate Change Mitigation and Agriculture: Designing projects and policies for smallholder farmers. In Wollenberg E, Tapio-Biström ML, Grieg-Gran M, Nihart A. Climate Change Mitigation and Agriculture. London and New York: Routledge; 2012. p. 3-28.

[8] Rockstrom JSW, Noone K, Persson A, Chapin F, Lambin E, Lenton T et al. A safe operating space for humanity. Nature. 2009 September 24: p. $472-475$.

[9] Conservation AW. FAQ-Water Supply, sources and Agricultural Use. [Online]; 2009 [cited 2012 June 4. Available from: http://www.agwaterconservation.colostate.edu/Default.aspx.

[10] Rockstrom J, Lannerstad M, Falkenmark M. Assessing the water challenge of a new green revolution in developing countries. Proceedings of the National Academy of Sciences of the United States of America. 2006 April 10; 104(15): p. 6243-6260.

[11] Steffen W, Grinevald J, Crutzen P, McNeill J. The Anthropocene: conceptual and historical perspectives. Philosophical Transactions of the Royal Society. 2011; 369: p. 842-867.

[12] Sadoff C, Muller M. Water Management, Water Security and Climate Change Adaptation: Early Impacts and Essential Responses. Stockholm; 2009.

[13] Pretty J, Noble A, Bossio D, Dixon J, Hine E, Penning de Vries FMJ. Resource-Conserving Agriculture Increases Yields in Developing Countries. Environmental Science and Technology. 2006; p. 1-5.

[14] Smith P, Martino D, Cai Z, Gwary D, Janzen H, Kumar P et al. Greenhouse gas mitigation in agriculture. Philosophical Transactions of the Royal Society. 2008; 363: p. 789-313.

[15] McCarthy N, Branca G, Lipper L, Jolejole MC. Climate Smart Agriculture: A Synthesis of Empirical Evidence of Food Security and Mitigation Benefits from Improved Cropland Management. Mitigation Change in Agriculture Series. Rome; 2011.

[16] Pretty J, Sutherland WJ, Ashby J, Auburn Jea. The top 100 questions of importance to the future of global agriculture. International Journal of Agricultural Sustainability. 2010; 8(4): p. 219-236.

[17] Bryan E, Ringler C, Okoba B, Koo J, Herrero M, Silvestri S. Agricultural Management for Climate Change Adaptation, Greenhouse Gas Mitigation, and Agricultural Productivity: Insights from Kenya; 2011.

[18] Reganold JP, Papendick RI, Parr JF. Sustainable Agriculture. Scientific American. 1990 June: p. 112-120. 
[19] Makurira H, Savenije HHG, Uhlenbrook S, Rockstrom J, Senzanje A. The effect of system innovations on water productivity in subsistence rainfed agricultural systems in semi-arid Tanzania. Agricultural Water Management. 2011 July 5; 98: p. 1696-1703.

[20] Bellarby J, Foereid B, Hastings A, Smith P. Cool Farming: Climate impacts of agriculture and mitigation potential. University of Aberdeen; 2008.

[21] UN. UN Water. [Online].; 2005 [cited 2013 June 1. Available from: http://www.un.org/waterforlifedecade/scarcity.shtml.

[22] FAO. FAONewsroom. [Online].; 2007 [cited 2013 January 5. Available from: http://www.fao.org/newsroom/en/focus/2007/1000521/.

[23] Allan A, Rieu-Clarke A. Good Governance and IWRM-a legal perspective. Irrigation and Drainage Systems. 2010 October 12; 24: p. 239-248.

[24] Cotulla L, Hesse C, Syllla O, Thebaud B, Vogt G, Vogt K. Land and Water Rights in the Sahel. Stockholm; 2010.

[25] Stamm V, Sawadogo JP, Ouedraogo SR, Ouedraogo D. Micro-policies on land tenusre in three villages in Bam provice, Burkina Faso: Local strategies for exchanging land. Issue Paper no. 124. Stockholm; 2003.

[26] Burney JA, Naylor RL. Smallholder Irrigation as a Poverty Alleviation Tool in sub-Saharan AFrica. World Development. 2011; 40(1): p. 110-123.

[27] Wallace J. Increasing agricultural water use efficiency to meet future food production. Agriculture, Ecosystems and Environment. 2000; p. 105-119.

[28] Dillon A. The Effect of Irrigation on Poverty Reduction, Asset Accumulation, and Informal Insurance: Evidence from Northern Mali. World Development. 2011; 39(12): p. 2165-2175.

[29] Bossio D, Jewitt G, van der Zaag P. Smallholder system innovation for integrated watershed management in Sub-Sahran Africa. Agricultural Water Management. 2011; 98(11): p. 1683-1686.

[30] UNDP. Official Development Assistance; 2010.

[31] OECD. OECD. [Online].; 2013. Available from: http://www.oecd.org/investment/stats/developmentaidreachesanhistorichig hin2010.htm.

[32] Lowder S, Carisma B. Financial Resource Flows to Agriculture. ESA Working Paper. New York: FAO; 2011.

[33] Pardey PG, Alston JM, Piggott RR. Shifting Ground: Agriculture R\&D Worldwide. Washington, D.C.; 2006.

[34] IFPRI. Green Revolution: Curse or Blessing. Washington D.C.; 2002.

[35] Conway G. The Doubly Green Revolution: Balancing Food, Poverty and Environmental Needs in the 21st Century. In Conway G. Doubly Green Revolution: Food for All in the 21st Century. Ithaca: Conway; 1999. p. 1-17.

[36] FAO. Food and Agriculture Organization of the United Nations. [Online]. cited 2012 August $30 . \quad$ Available from: www.fao.org/nr/water/aquastat/data/quesry/results.html.

[37] Hussain I, Hanjra M. Irrigation and Poverty Alleviation: Review of the Empirical Evidence. Irrigation and Drainage. 2004; 53: p. 1-15. 
[38] Pimentel D, Berger B, Filiberto D, Newton M, Wolfe B, Karabinakis E et al. Water Resources: Agricultural and Environmental Issues. BioScience. 2004 October; 54(10): p. 909-918.

[39] Mollinga P, Meinzen-Dick R, Merrey D. Politics, Plurality and Problemsheds: A Strategic Approach for Reform of Agricultural Water Resources Management. Development Policy Review. 2007; 25(6): p. 699-719.

[40] Merrey DJ. Is Normative Integrated Water Resources Management Implementable? In 8thWaterNet/WARFSA/GWP-SA Symposium: IWRMFrom Concept to Practice; 2007; Livingstone, Zambia: IW Learn. p. 1-14.

[41] Burney JA, Naylor RL. Smallholder Irrigation as a Poverty Alleviation Tool in sub-Saharan AFrica. World Development. 2011; 40(1): p. 110-123.

[42] You LZ. Africa Infrastructure Country Diagnostic: Irrigation Investment Needs in Sub-Saharan Africa. Background Paper 9. Washington D.C.; 2008.

[43] Irrigation Association. Irrigation Association. [Online]. Available from: https://www.irrigation.org/Certification/Certification_Programs.aspx.

[44] UN. Millenium Development Goals. [Online]; 2012. Available from: http://www.un.org/millenniumgoals/pdf/2012_Progress_E.pdf. 